\author{
Maryam AMAN \\ Abdul WAHEED \\ Malik Asghar NAEEM \\ Syed Akhtar Ali SHAH
}

\title{
Izvajanje koncepta skupnega prometnega prostora s preobrazbo ulic v poslovnem središču Pešavarja v Pakistanu
}

Zamisel o skupnem prometnem prostoru (ang. living streets) se je razvila šele nedavno, upošteva pa se predvsem pri prostorskem načrtovanju in razvoju mest. Njena glavna namena sta zagotavljanje varnega dostopa za vse vrste prometa in $s$ tem osredotočanje na splošni trajnostni razvoj mesta. Avtorji v članku proučujejo značilnosti glavnih prometnih žil v poslovnem središč Pešavarja z vidika koncepta skupnega prometnega prostora, na podlagi česar bi se lahko sprejeli ustrezni ukrepi za izboljšanje tega mestnega območja. Predpostavljajo, da trenutna infrastruktura skupnega prometnega prostora $\mathrm{v}$ poslovnem središču mesta ne zadovoljuje potreb različnih uporabnikov (nakupovalcev, stanovalcev, zaposlenih in ljudi, ki območje uporabljajo za rekreacijo). Da bi določili in anali- zirali osnovno javno infrastrukturo v poslovnem središču mesta, so opravili raziskavo, ki je vključevala opazovanje in anketo. Raziskava je razkrila težave, kot so hrup, onesnažen zrak, smeti, pomanjkanje ustrezne javne prometne infrastrukture in površin za pešce ter slabo upravljanje prometa. Anketiranci so izrazili močno nezadovoljstvo z zdajšnjo ureditvijo za pešce in parkiranje na ulici. Terenska raziskava je poleg tega pokazala, da površine za pešce ne zadovoljujejo potreb pešcev, pomanjkanje ulične opreme pa prebivalce odvrača od tega, da bi se bolj družili.

Ključne besede: skupni prometni prostor, varnost pešcev, privlačnost za bivanje, preureditev v območja za pešce, dostopnost, poslovna središča, trajnostnost 


\section{Uvod}

Privlačnost za bivanje (ang. liveability) je sestavni del koncepta trajnostnega mestnega razvoja (Dempsey idr., 2011). Spodbujanje hodljivosti in dostopnosti na podlagi različnih načinov prevoza je eden glavnih ciljev prevoznega sektorja, povezanih $s$ privlačnostjo za bivanje in trajnostnim razvojem (Victoria Transport Policy Institute, 2010). To kaže na pomembno vlogo hodljivosti z vidika privlačnosti mesta za bivanje, saj spodbuja oblikovanje okolju prijaznih in trajnostnih območij ter lokacij, privlačnih za bivanje (Shamsuddin idr., 2012). Leta 2013 je bila v okviru programa Združenih narodov za naselja UN-Habitat predstavljena zamisel o blaginji mest (ang. city prosperity), ki predvideva, da ima mesto ulice s potencialom, ki kot javni prostori spodbujajo druženje, krepijo varnost, izboljšujejo gospodarsko in ekološko trajnost ter zagotavljajo dostop motoriziranemu in nemotoriziranemu prometu (UN-Habitat, 2013). Pri konceptu mesta, privlačnega za bivanje, je močan poudarek na uvajanju trajnostnih oblik prevoza, ki pomagajo zmanjšati onesnaženost zraka in hrup ter spodbujajo prebivalce $\mathrm{k}$ hoji oziroma hodljivost, ki se lahko doseže z ureditvijo skupnega prometnega prostora (Lennard, 2008). Glavni cilj uvedbe skupnega prometnega prostora je narediti mesto varno in dostopno (Dempsey idr., 2011).Z njo postanejo alternativni načini prevoza ljudem privlačnejši, hkrati pa oblasti spodbudi $\mathrm{k}$ preobrazbi javnih prostorov, s čimer postanejo ulice varnejše in živahnejše za prebivalce (Dumbaugh in Gattis, 2005). Po podatkih Svetovne zdravstvene organizacije se po svetu vsako leto v prometnih nesrečah poškoduje približno 50 milijonov ljudi, 1,2 milijona pa jih umre. Če ne bodo sprejeti novi ukrepi za preprečevanje prometnih nesreč, se bodo te številke v prihodnjih 20 letih predvidoma povečale za $65 \%$ (Gulzar idr., 2012). Današnje ceste niso zgrajene kot monofunkcionalne enote, ki jih lahko uporabljajo samo avtomobili, ampak so oblikovane tako, da jih lahko hkrati uporabljajo različni udeleženci v prometu, tj. kolesarji, pešci in vozniki osebnih vozil (Pojani in Stead, 2015). V Pešavarju je cestno omrežje namenjeno samo motornim vozilom, saj so bile ceste zgrajene kot monofuncionalne enote, ki pogosto nimajo niti najosnovnejše ulične opreme (Borthakur, 2017). Ljudje se spopadajo z ovirami, kot so ulični prodajalci na pločnikih in nedovoljeno parkiranje, ki omejujejo njihovo mobilnost $\mathrm{v}$ poslovnem središcu. Avtorji v članku analizirajo trenutno infrastrukturo v poslovnem središču Pešavarja z vidika koncepta skupnega prometnega prostora in predpostavljajo, da ne zadovoljuje potreb različnih uporabnikov (nakupovalcev, stanovalcev, zaposlenih in ljudi, ki območje uporabljajo za rekreacijo).

\section{Značilnosti skupnega prometnega prostora}

Cilj skupnega prometnega prostora (ang. living streets ali complete streets) je zagotoviti prometni sistem za vse uporabnike, vključno $s$ pešci, kolesarji in vozniki. Sestavljen je iz kolesarskih poti, površin za pešce, ulične opreme, ukrepov umirjanja prometa, prometnih otokov, prehodov za pešce in podobnih prvin. Ključno za njegovo oblikovanje je ustvarjanje naravne, funkcionalne in prijetne ulične krajine (Burden in Litman, 2011).

Za skupne prometne prostore ni univerzalnega načrta, saj je vsak drugačen in zadovoljuje izključno potrebe svoje skupnosti in okolice. Skupni prometni prostor lahko sestavljajo prometni pasovi za avtobuse, pločniki, kolesarske poti, prometni otoki, postajališča javnega prometa, semaforji in prehodi za pešce, razširitve pločnikov, ožji prometni pasovi, krožǐšča in druge podobne prvine (Bain idr., 2012). Zamisel o skupnem prometnem prostoru se je močneje razvila $\mathrm{v}$ zadnjih desetletjih, zdaj pa se upošteva pri načrtovanju in razvoju mest po svetu (Chourabi idr., 2012). Koncept skupnega prometnega prostora ni omejen samo na ureditev pločnikov in kolesarskih poti, ampak se osredotoča na splošen trajnostni razvoj mesta. Pri snovanju skupnega prometnega prostora je pozornost usmerjena na mikroraven, kar omogoča, da se urbanisti osredotočijo na pešce in pločnike ter spodbujajo oblikovanje gosto pozidanih sosesk. Stanovalci pa se zaradi tega raje odločajo za hojo in kolesarjenje kot vožnjo z avtomobilom. S skupnimi prometnimi prostori postanejo soseske varnejše, funkcionalnejše, udobnejše in dostopnejše, kar spodbuja medosebne odnose in s tem razvoj celotne skupnosti (Gehl, 2013).

Podpiranje zdravega okolja, izboljšsevanje življenjskih razmer v soseskah, razvoj skupnosti in spodbujanje ljudi k uporabi javnih prostorov so ključne prvine koncepta skupnih prometnih prostorov, $s$ katerimi se ukvarjajo urbanisti po vsem svetu (Carmona, 2010; Gehl, 2011). Skupni prometni prostori poleg tega pomagajo pri oblikovanju bolj trajnostnega mesta, saj zmanjšujejo onesnaženost ter med prebivalci krepijo zdravje in zadovoljstvo (Farr, 2011). Posebna prvina privlačnosti za bivanje je tudi kakovost življenja in ker sta ta dva pojma močno prepletena, se običajno uporabljata kot sinonima. Upoštevanje kakovosti življenja je torej ključno pri oblikovanju skupnega prometnega prostora na podlagi zamisli o privlačnosti za bivanje (Miller idr., 2013). Povezanost teh dveh prvin hkrati izraža močno povezavo med različnimi značilnostmi razmer in krajev, ki vplivajo na splošna prizadevanja za vzpostavljanje kraja (ang. place making; Appleyard idr., 2014). Na podlagi 
izsledkov v literaturi opozarjajo na številne prvine skupnega prometnega prostora, ki imajo pomembno vlogo pri izboljšanju dinamike mesta in življenjskih razmer v njem. Vsaka prvina pa ne more biti vključena v vsako mesto, saj se različna mesta spopadajo z različnimi težavami (Eckerson, 2010).

Večina raziskovalcev meni, da je ureditev kolesarskih poti najboljši način izboljšanja mestne krajine, saj pomagajo zmanjšati prevlado avtomobilov (Barnett, 2018). Kolesarske poti poleg tega zmanjšujejo onesnaženost in prometne zastoje, zaradi česar postane mesto dostopnejše in okolju prijaznejše (Bain idr., 2012). Ulična krajina soseske je ločen ekosistem, ki je poleg številnih drugih sistemov sestavljen iz gospodarskega sistema, družbenega sistema, zelenih mestnih površin in prometnega sistema. Ekosistem ulične krajine posnema naravo in ustvarja vzajemne odnose v medsebojno prepletenem sistemu, s čimer trajnostno izboljša lokalno gospodarstvo, naravno okolje ter vire soseske in njenih prebivalcev (Pucher in Buehler, 2011). Tudi klopi, razsvetljava, krajinsko urejene površine in drevesa so del ulične krajine. Imajo pomembno vlogo pri ustvarjanju živahnega utripa na ulicah in povečajo dinamičnost soseske. Uporaba avtohtonih rastlin je za ulično krajino ključna, saj te rastline najbolje rastejo v svojem avtohtonem okolju. Namestitev klopi za pešce krepi lokalno gospodarstvo in poskrbi za živahnejše ulice, na katerih se lahko domačini sprehajajo, dobivajo s prijatelji, nakupujejo in preživljajo prosti čas (McPherson idr., 1999). Pri sodobnem urbanističnem načrtovanju se pogosto zanemarja pomen območij za pešce, saj se urbanisti raje osredotočajo na zmanjšanje motečega vpliva pešcev na ulicah. To zlahka dosežejo z uvedbo zvišanih pločnikov, gradnjo pešcon med stavbami in drugimi rešitvami, ki poskrbijo za to, da se pešci ne zadržujejo na cestah. Cilj koncepta skupnega prometnega prostora pa je vrniti ljudi na ulice na podlagi oblikovanja javnih prostorov, privlačnih za pešce (Bain idr., 2012). Tudi za ulično opremo se je izkazalo, da spodbuja pešce k temu, da se pogosteje zadržujejo na ulicah, saj v soseski ustvarja okolje, prijazno nemotoriziranemu prometu (Soltani in Bosman, 2005). Ulična oprema najpogosteje vključuje stebričke, klopi, avtomate za prodajo časopisov, informativne table, javno umetnost, korita za rože, smetnjake, pločnike, javna stranišča in parkomate. Te prvine izboljšajo utrip ulice, saj postaneta zaradi njih kolesarjenje in hoja privlačnejša. Namestitev ulične opreme pa je odvisna od razporeditve ulične razsvetljave in dreves, ki določajo ulično podobo (Dempsey idr., 2011).

\subsection{Izbrani primeri izvajanja koncepta skupnega prometnega prostora}

V nadaljevanju so navedeni primeri izvajanja koncepta skupnega prometnega prostora iz različnih mest po svetu, pri čemer je eden najuspešnejših primerov New York. Čeprav se Pešavar po številu prebivalstva in velikosti ne more primerjati z New Yorkom, ima podobno mestno tkivo. Uprava New Yorka je uspešno uvedla različne prvine skupnega prometnega prostora, kot sta ulična oprema in omejen dostop vozil, ki sta povečala število pešcev. Po drugi strani pa se Kuala Lumpur spopada s podobnimi težavami kot Pešavar, kar se je izkazalo za uporabno pri proučevanju potreb uporabnikov poslovnega središča Pešavarja.

\subsubsection{Preobrazba javnih prostorov v New Yorku}

Po vsem mestu so bili urejeni območja za pešce in ulične terase, zaradi katerih ljudje ne parkirajo več na ulicah. Ta območja so oblikovana tako, da ljudi privlačijo s senco in površinami za sedenje. Večina križiščc, na katerih je prevladoval motorizirani promet, je bila preoblikovana $\mathrm{v}$ ulične terase, ki so pomagale umiriti promet in so ustvarile varnejše površine za pešce (Hou, 2010; Shaftoe, 2012). Na gosto pozidanih območjih so nekatere ulice povsem zaprte za promet in napolnjene $\mathrm{z}$ ulično opremo, kar je ključno za ulične terase, kjer se ljudje lahko usedejo in sprostijo. Zelo gosto pozidana območja imajo le malo odprtih površin ali teh sploh ni, zato na novo urejena območja za pešce prebivalcem nudijo prostor za druženje (Gehl, 2013). Opisani ukrepi bi lahko izboljšali tudi družbenoekonomske razmere v poslovnem središču Pešavarja.

\subsubsection{Ulice v azijskih mestih: hodljivost v Kuala Lumpurju}

Iz izsledkov več raziskav, opravljenih v Kuala Lumpurju, je razvidno, da so tamkajšnje turistične destinacije dokaj primerne za pešačenje, manjše ulice pa ponujajo le malo prostora za pešce, kar vpliva na splošno turistično izkušnjo, saj avtomobili prevladujejo na večini mestnih ulic (Sreetheran idr., 2011). Raziskave so pokazale še, da bi bilo treba za oblikovanje skupnega prometnega prostora izboljšati razsvetljavo in prehode za pešce, s čimer bi se povečala varnost območja ponoči in čez dan. Za prijetno sprehajanje turistov in domačinov pa bi bili potrebni tudi osenčeni in širši pločniki. Izkazalo se je, da je varna in prijetna hoja najpomembnejši dejavnik, ki vpliva na izboljšsanje izkušnje pešcev v mestnem središču (Zakaria in Ujang, 2015). Za uvedbo skupnega prometnega prostora so torej pomembne različne prvine, kot so razsvetljava, prehodi za pešce ter osenčeni in širši pločniki.

\subsubsection{Skupni prometni prostori v Indiji}

Prizadevanja za spodbujanje hodljivosti in infrastrukture za pešce $\mathrm{v}$ šestih indijskih mestih $\mathrm{v}$ sodelovanju $\mathrm{z}$ azijsko razvojno banko so pokazala, da so za preobrazbo mestnih ulic potrebni obsežni projekti, ki vključujejo več kot samo izboljšanje prometnih razmer (Leather idr., 2011). Dodatne raziskave so 
pokazale, da se $\mathrm{v}$ različnih mestih po Indiji izvajajo manjši projekti za izboljšanje hodljivosti, obsežnejši projekti pa se ne načrtujejo. Razen obnove nekaj kilometrov pločnikov drugi večji posegi niso načrtovani. Večina gradbenega sektorja se namesto tega raje osredotoča na širjenje cestnega omrežja za avtomobile in javni promet (Datey idr., 2012). Izboljšanje javnega prevoza je potrata kapitala, saj se ne izbolǰ̌uje njegova dostopnost, to pa lahko povzroči upad števila potnikov tudi na novi infrastrukturi, ki se trenutno gradi (Leather idr., 2011). V Suratu so načrtovani podhodi in desetmetrski nadhodi, v Čenaju pa je inštitut za prometno in razvojno politiko na podlagi načel skupnega prometnega prostora uredil kolesarske poti v mestu kot del pilotnega projekta. Osnutek glavnega načrta predvideva širše pločnike vzdolž stanovanjskih in glavnih trgovsko-poslovnih ulic ter poskuša preprečiti, da bi si pločnike prisvojili ulični prodajalci, da bi na njih ljudje parkirali vozila ali da bi nanje nameščali električne transformatorje, reklamne panoje in druge prvine. V mestu Pune sta indijski tehnološki inštitut iz Delhija (IIT Delhi) in indijski centralni inštitut za cestni prevoz (CIRT) zasnovala glavni načrt gradnje sistema hitrih avtobusov, ki vključuje tudi podhode za pešce vzdolž poskusnega koridorja, projekt pa obsega tudi gradnjo nadhodov (Bhattacharyya in Mitra, 2013). Navedeni primeri so pomembni, saj imata Pakistan in Indija skoraj enako kulturno in socialno strukturo, uporabniki poslovnih mestnih središč v obeh državah pa se spopadajo s podobnimi težavami. Študija primerov iz Indije je torej pokazala, da projekti manjšega obsega ne morejo izboljšati dostopnosti pešcev in da je za reševanje tega problema potreben celostni pristop.

\subsection{Načrtovanje in raba javnih prostorov $\mathbf{v}$ Pešavarju}

Že več kot dve desetletji se Pešavar, glavno mesto pakistanske province Kiber Paktunkva, spopada s težavami, ki jih povzroča urbanizacija, te so prometni zastoji, naraščanje števila prometnih nesreč, onesnažen zrak, smeti in hrup (Hashmi, 2016). V zadnjem desetletju je število njegova prebivalstva skokovito naraslo, razlogi za to pa so zelo različni (naval notranje razseljenih ljudi, naravna rast prebivalstva in množične migracije zaradi političnih nemirov). Zaradi vsega naštetega se je neverjetno povečalo število lastnikov osebnih vozil, kar povzroča onesnaženost zraka, hrup, vse večjo porabo fosilnih goriv in prometne nesreče. Težava pa ni samo urbanizacija, ampak tudi dejstvo, da je Pešavar že več kot dvajset let edino zatočíšč za afganistanske begunce in Pakistance, ki so notranje razseljeni zaradi političnih nemirov v državi. Naravna rast števila prebivalstva ter pritok afganistanskih beguncev in notranje razseljenih Pakistancev sta glavna vzroka za hitro rast števila prebivalcev Pešavarja, zaradi katere je bilo treba zgraditi dobro načrtovano cestno omrežje. Mestna uprava je to zagotovila tako, da je v mestu zgradila glavne prometne žile (Peshawar Development Authority, 2017), ki pa jih lahko uporabljajo samo avtomobili, saj so bile oblikovane kot monofunkcionalne ceste (Borthakur, 2017). V zadnjih 40 letih sta se tako močno povečali števili prebivalcev in avtomobilov, razširjena so bila tudi cestna omrežja, $s$ tem pa se je hkrati povečala tudi nevarnost trkov ali prometnih nesreč (Hyder idr., 2000). V letih 2010 in 2011 je bilo v Pakistanu skupno 9.723 prometnih nesreč, od tega $2.722 \mathrm{v}$ provinci Kiber Paktunkva (Pakistan Bureau of Statistics, 2012). V letih 2015 in 2016 se je skupno število nesreč zmanjšalo na 9.100 , pri čemer se jih je 4.287 zgodilo v provinci Kiber Paktunkva (Pakistan Bureau of Statistics, 2012). V teh petih letih se je skupno število nesreč v državi zmanjšalo, $\mathrm{v}$ provinci Kiber Paktunkva pa se je skoraj podvojilo.

V Pešavarju so bile ulice vedno prilagojene motoriziranemu prometu, kar je $\mathrm{v}$ nasprotju s konceptom skupnih prometnih prostorov in trajnostnih ulic, ki zadovoljujejo potrebe različnih udeležencev v prometu na isti ulici in dajejo prednost pešcem, ki po ulici hodijo in jo doživljajo kot javni prostor (Gulzar idr., 2012). Pešavarski odsek za urbanistično politiko se ukvarja z urbanističnimi projekti, ki naj bi izboljšali razmere, vendar tem projektom manjkajo celostni pristop in nekatere oblikovne prvine, povezane $\mathrm{z}$ načeli trajnostnega razvoja, kot so enakost in enakopravnost, izboljšana kakovost življenja uporabnikov poslovnega središča in lepše okolje. Te prvine je treba vključiti v poslovno središč mesta, da bi izboljšali družbenoekonomski položaj tega območja in zadovoljili potrebe različnih udeležencev v prometu.

\section{Gradivo in metode}

Avtorji so v raziskavi uporabili kvalitativne in kvantitativne metode ter na podlagi zbranih podatkov analizirali ulice $\mathrm{v}$ poslovnem središču Pešavarja. Mešane metode so uporabili zato, ker so bile primerne za iskanje odgovorov na raziskovalna vprašanja, povezana z glavnimi prometnimi žilami v poslovnem središču, hkrati pa so pomagale pojasniti razloge za trenutne razmere. Cilj raziskave je izboljšati prometne razmere v poslovnem središcu Pešavarja, tako da bi bile zadovoljene tudi potrebe nemotoriziranega prometa, pri čemer je določanje ulic, ki bi jih bilo treba spremeniti v skupni prometni prostor, odvisno od značilnosti posamezne ulice. Avtorji so na različnih delih proučevanega območja izvedli terensko raziskavo, $s$ katero so določili in analizirali osnovne značilnosti proučevanega območja ter je vključevala opazovanje in anketo. Tamkajšnje razmere in zadovoljstvo uporabnikov $z$ različnimi prvinami so analizirali na podlagi indeksa zadovoljstva.

- Terenska raziskava in opazovanje: ulice v poslovnem središču Pešavarja imajo različne značilnosti, zato so av- 
torji določili tiste, ki še slabšajo razmere na proučevanem območju. To so storili tako, da so si izbrane ulice ogledali in jih fotografirali. Pridobljeni kvalitativni podatki so jim pomagali razumeti razmere na proučevanem območju, pri čemer so avtorji oblikovali seznam kazalnikov, ki so jih določili na podlagi pregleda literature. Kazalnike so upoštevali tudi pri pripravi vprašalnika za anketo, vključevali pa so dogajanje na ulici, glavne razloge za gibanje na ulici, ulično zasnovo, dostopnost, težave, povezane $s$ parkiranjem in s kolesarjenjem, površine za pešce, razsvetljavo, varnost, ulično opremo in čistočo (Majeed, 2012; Nilles, 2016). Navedeni kazalniki so bili izbrani, ker so bili pomembni za raziskavo.

- Anketa: z anketo so avtorji določili družbenoekonomski položaj lokalnih prebivalcev, njihove skrbi glede trenutnih razmer in njihove preference $\mathrm{v}$ zvezi s skupnim prometnim prostorom na proučevanem območju. Ker so avtorji za anketo izbrali del poslovnega vozlišča mesta, so velikost vzorca izračunali na podlagi formule, ki sta jo razvila Krejcie in Morgan (1970). V skladu s to formulo je bilo v anketo vključenih 123 oseb. Interval zaupanja je znašal $95 \%$, kar je zagotavljalo točnost raziskave. Med anketiranci so bili uporabniki proučevanega območja, izbrani pa so bili s sistematičnim naključnim vzorčenjem, kar je zagotavljalo nepristranskost raziskave. Vsak deseti anketiranec je moral izpolniti vprašalnik, ki so ga avtorji sestavili za zbiranje primarnih podatkov.

- Indeks zadovoljstva: avtorji so stopnjo zadovoljstva izračunali na podlagi indeksa zadovoljstva, ki ga je razvil Yeh (1972). Z njim so primerjali zadovoljstvo anketirancev s parkirišči na proučevanem območju. Vrednost $+1,00$, pomeni močno zadovoljstvo, vrednost 0,00 pomeni sprejemljivo zadovoljstvo, vrednost $-1,00$ pa nakazuje nezadovoljstvo (Yeh, 1972, 1975). Indeks je bil uporabljen že v več raziskavah (Anwar idr., 2008) in se je izkazal kot učinkovit pokazatelj stopnje zadovoljstva ali nezadovoljstva (Abdu idr., 2014). Za merjenje zadovoljstva uporabnikov so bile uporabljene naslednje spremenljivke: površine za pešce, parkirišča, kolesarska infrastruktura, infrastruktura za pešce ter njena dostopnost in vzdrževanje, varni prehodi, ukrepi umirjanja prometa, zeleni nasadi kot vmesna varovalna območja, ulična oprema, varnost in čistoča. Z oceno zadovoljstva so lahko avtorji raziskave bolje razumeli potrebe in zahteve uporabnikov glede izboljšanja dostopnosti proučevanega območja.

Podatki, pridobljeni s terensko opazovalno raziskavo, so bili vneseni v statistični program SPSS, v katerem so avtorji analizirali pogostost odgovorov. Tabelarne rezultate, pridobljene z analizo v tem programu, so nato v Excelu pretvorili v grafično obliko. Za analizo zadovoljstva anketirancev z varnostjo, vidljivostjo, preprostostjo uporabe in drugimi kazalniki so uporabili indeks zadovoljstva, ki so ga uporabili tudi pri analizi preferenc anketirancev glede morebitne prihodnje ulične opreme, prehodov za pešce, izboljšanih pločnikov in podobnega.

\section{4 Študija primera v Pešavarju: izsledki in razprava}

Z vidika prometnih razmer je Pešavar eno izmed prometno najbolj obremenjenih in onesnaženih mest v Pakistanu. Prevelik promet na ozkih cestah in dejstvo, da se trgovine in tržnice širijo na cesto, povečujeta obremenjenost že tako prenatrpanega cestnega omrežja. Zlasti za ženske in otroke je pešačenje skoraj nemogoče, saj pločnike $\mathrm{v}$ glavnem zasedajo ulični prodajalci. Opisano vse bolj povečuje hrup in onesnaženost zraka v mestu, saj je v njem zelo malo zelenih površin (Ali idr., 2012). Zaradi močne rasti števila prebivalstva vsako leto hitro narašča tudi število registriranih vozil (The Urban Unit, 2016), delež nemotoriziranega prometa v mestu, v katerega spadajo tudi pešci, pa je samo $2 \%$. Razlogi za tako majhen delež so pomanjkanje ustrezne infrastrukture (pločnikov in semaforjev), šibka varnost zaradi slabega sistema nadzora prometa, slabe povezave za pešce med omrežjem javnega prevoza in različnimi dejavnostmi in objekti v mestu ter to, da javni organi neustrezno izvajajo predpise (The Urban Unit, 2016).

Podatki za obdobje 2003 - 2012 kažejo, da se je v desetih letih število prometnih nesreč na trgovsko-poslovnih območjih, kot je Saddar, povečalo. V tem obdobju se je v soseski Saddar zgodilo 39 smrtnih nesreč in 155 nesreč brez smrtnega izida. $\mathrm{V}$ nesrečah je umrlo 40 ljudi, med katerimi je bilo $70 \%$ pešcev, poškodovalo pa se je 189 ljudi, od tega $50 \%$ pešcev (Shah, 2014). Podatki kažejo, da je mobilnost omejena zaradi slabe dostopnosti in povezanosti različnih dejavnosti, prevladujočih družbenoekonomskih značilnosti območja, nepremišljenega urbanističnega načrtovanja in slabe infrastrukture javnega prevoza. Ključno je torej razumeti trenutne razmere na tem območju in težave tamkajšnjih prebivalcev in obiskovalcev (The Urban Unit, 2016). Avtorji so za raziskavo izbrali sosesko Saddar, ki velja za največje trgovsko-poslovno vozlišče v Pešavarju, saj meri 17,5 ha. Na sliki 1 so prikazane ceste in ulice, ki so bile izbrane za terensko raziskavo (npr. ulica Saddar, ki poteka od severovzhoda do jugozahoda).

Z vprašalnikom so avtorji od anketirancev pridobili demografske podatke, prikazane na sliki 2 . S slike je razvidno, da je bila večina obiskovalcev proučevanega območja moških. Mobilnost žensk je bila na trgovsko-poslovnem območju omejena in dokaj očitna, saj je bilo anketirank manj kot četrtina. Kot so navedle številne anketiranke, je bil glavni razlog za te razlike med spoloma slabo stanje površin za pešce. Delež žensk bi se mogoče povečal, če bi se razmere na tovrstnih trgovskih 


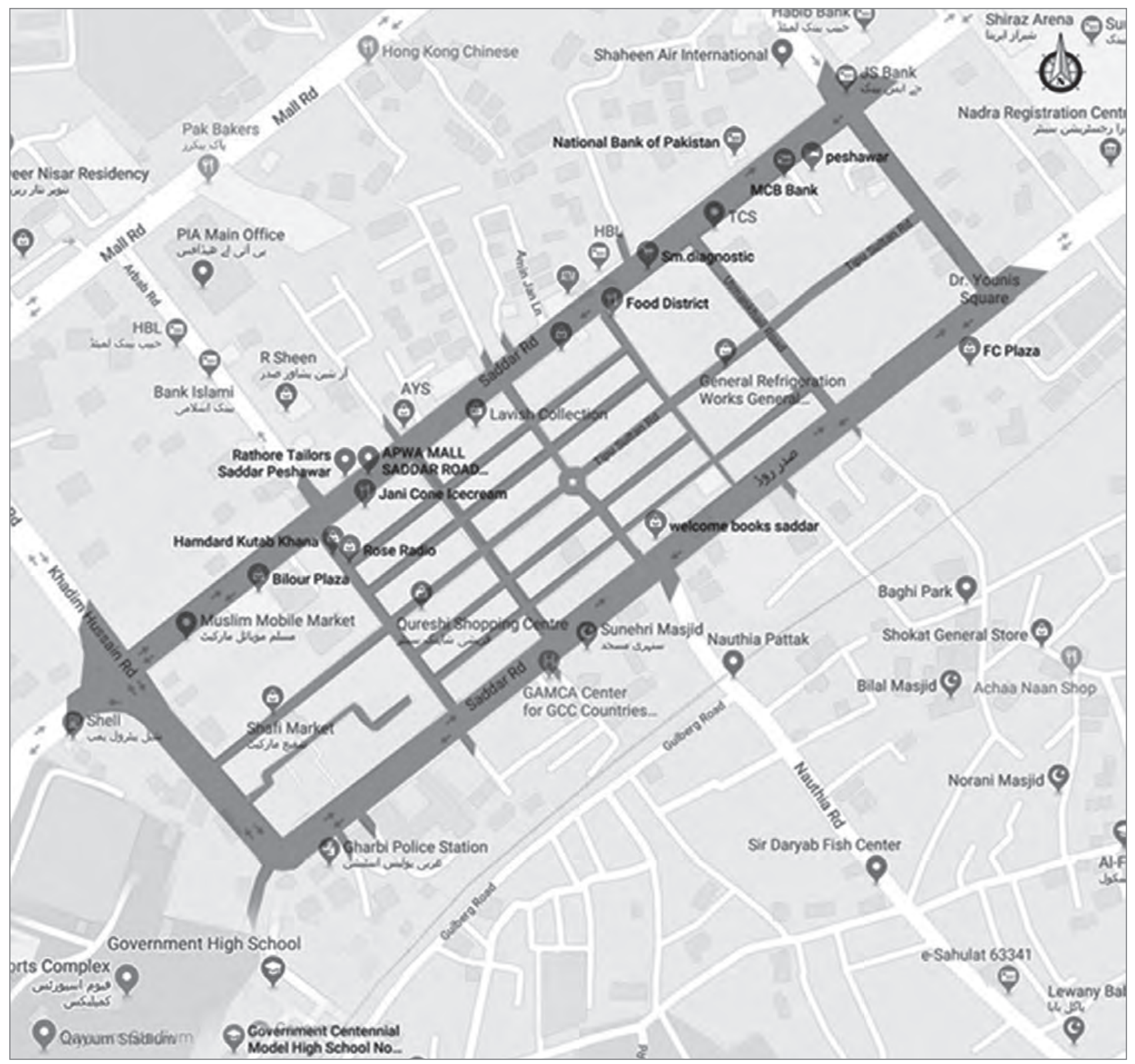

Slika 1: Zemljevid proučevanega območja (vir: Google Maps, 2019)

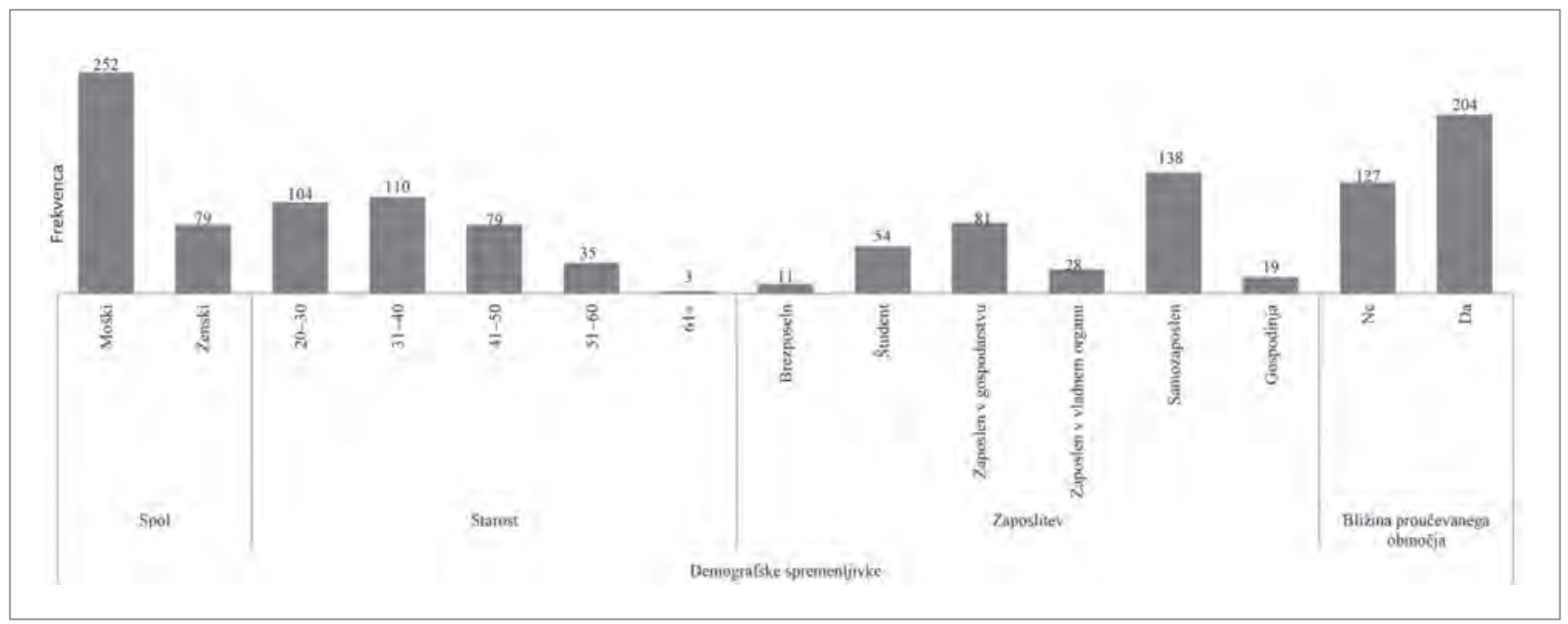

Slika 2: Demografske značilnosti anketirancev (vir: terenska raziskava) 
Preglednica 1: Ocena razpoložljivosti osnovnih cestnih in prometnih prvin

\begin{tabular}{|c|c|c|}
\hline Dejavnost & Značilnosti & $\mathrm{Da} / \mathrm{ne}$ \\
\hline \multirow{3}{*}{ Dogajanje na ulici } & Kavarne/zunanje površine za sedenje & $\mathrm{Ne}$ \\
\hline & Ovire na pločnikih, ki jih ustvarjajo ulični prodajalci & $\mathrm{Da}$ \\
\hline & Kažipoti za pešce & $\mathrm{Ne}$ \\
\hline \multirow{10}{*}{ Promet } & Hitrost vozil je primerna in ne ogroža varnosti pešcev & $\mathrm{Ne}$ \\
\hline & Osnovni ukrepi za umirjanje prometa & $\mathrm{Da}$ \\
\hline & Dodatni ukrepi za umirjanje prometa & $\mathrm{Ne}$ \\
\hline & Konflikti med različnimi udeleženci v prometu & $\mathrm{Da}$ \\
\hline & Hitrost voznikov omogoča varno pešačenje & $\mathrm{Ne}$ \\
\hline & Nevarnost zbitja pešcev & $\mathrm{Da}$ \\
\hline & Razpoložljivost različnih vrst prevoza & $\mathrm{Ne}$ \\
\hline & Avtobusna postajališča & $\mathrm{Ne}$ \\
\hline & Dobre tranzitne povezave & $\mathrm{Ne}$ \\
\hline & Pešci, ki izstopajo iz avtobusov, ovirajo promet & $\mathrm{Da}$ \\
\hline \multirow{4}{*}{ Srednji ločilni pas/prehodi za pešce } & Manjša križišča (z razširitvami pločnikov ali otoki za pešce) & $\mathrm{Ne}$ \\
\hline & Srednji ločilni pasovi & $\mathrm{Ne}$ \\
\hline & Prehodi & $\mathrm{Ne}$ \\
\hline & Ustrezna razsvetljava & $\mathrm{Ne}$ \\
\hline \multirow{4}{*}{ Rob cestišča } & Urejeni robni pasovi & $\mathrm{Ne}$ \\
\hline & Nadhodi/podhodi & $\mathrm{Ne}$ \\
\hline & Urejeno odvodnjavanje & $\mathrm{Ne}$ \\
\hline & Označena parkirišča ob robu ceste & $\mathrm{Da}$ \\
\hline \multirow{3}{*}{ Parkiranje } & Parkiranje na ulici & $\mathrm{Da}$ \\
\hline & Parkiranje zunaj ulice (na urejenih parkiriščih, v garažni hiši ipd.) & $\mathrm{Da}$ \\
\hline & Parkiranje ustvarja vmesni varovalni pas & $\mathrm{Da}$ \\
\hline \multirow{3}{*}{ Parkirna mesta za kolesa in druga vozila } & Ločene kolesarske poti & $\mathrm{Ne}$ \\
\hline & Kolesa na cesti & $\mathrm{Da}$ \\
\hline & Konflikti med vozniki in pešci & $\mathrm{Da}$ \\
\hline \multirow{8}{*}{ Pločniki } & Primerna ločenost motornih vozil in pešcev & $\mathrm{Da}$ \\
\hline & Razpoložljivost prehodov za pešce & $\mathrm{Ne}$ \\
\hline & Ukrepi za varno prečkanje ceste & $\mathrm{Da}$ \\
\hline & Ustrezna razsvetljava za pešce & $\mathrm{Ne}$ \\
\hline & Varnost med prometnimi konicami & $\mathrm{Da}$ \\
\hline & Dostopen vhod v stavbe & $\mathrm{Da}$ \\
\hline & Neprekinjeni pločniki & $\mathrm{Ne}$ \\
\hline & Ovire na pločnikih & $\mathrm{Da}$ \\
\hline \multirow{5}{*}{ Ulična oprema } & Ustrezna opremljenost pločnikov & $\mathrm{Da}$ \\
\hline & Smetnjaki, klopi ipd. & $\mathrm{Ne}$ \\
\hline & Ulična razsvetljava in semaforji & $\mathrm{Ne}$ \\
\hline & Rastline & $\mathrm{Ne}$ \\
\hline & Postajališča za taksije & $\mathrm{Ne}$ \\
\hline
\end{tabular}

Vir: terenska raziskava (2018) 
območjih izboljšale. Več kot polovica anketirancev je bila stara med 20 in 40 let, medtem ko je bil delež ljudi, ki so starejši od 60 let ter so bili opaženi in anketirani na tem območju, zelo zanemarljiv. V preglednici 1 so navedeni rezultati opazovalne raziskave, pri kateri so avtorji opazovali različne prvine izbranih delov proučevanega območja, kot so dogajanje na ulici, parkiranje, pločniki, prehodi za pešce, robovi cest, prometne razmere, ulična oprema, parkirna mesta za kolesa in druga vozila ter čistoča.

Avtorji so analizirali razmere v soseski Saddar, pri čemer so ugotovili, da so za to območje značilne najrazličnejše dejavnosti in z njimi povezane stavbe, od pisarn, trgovin na drobno in debelo, restavracij, objektov z zdravstvenimi storitvami, muzejev in verskih zgradb (mošeja, cerkev in tempelj) do velikih nakupovalnih centrov. Na podlagi empirične raziskave izbranega dela proučevanega območja so ugotovili, da je ulično dogajanje v smislu kavarn, zunanjih površin za sedenje in razpoložljivosti avtomatov za prodajo časopisov bolj šibko ali ga sploh ni. Naštete prvine naredijo poslovno središče mesta živahno in pritegnejo ljudi iz okoliških sosesk, kar poveča socialno enakost in gospodarsko vitalnost tega območja. Na proučevanem območju so pešci sedeli na pločniku, kar je poleg vozičkov uličnih prodajalcev ustvarjalo ovire in še večjo gnečo na že tako ozkem pločniku (slika 3).

Na proučevanem območju ni bilo semaforjev, kar bi bil lahko razlog za veliko prometnih nesreč, ki so se tam pripetile. $\mathrm{V}$ anketi je večina anketirancev izrazila nezadovoljstvo $\mathrm{z}$ infrastrukturo za pešce. Prometnih znakov za voznike ali pešce ni bilo, kar je še en pomemben povzročitelj trkov med vozili in pešci. Širina cestišča na vogalih ulic omogoča veliko hitrost pri zavijanju v desno, zaradi česar so pogosti trki med vozili in pešci. Anketiranci so izrazili močno zaskrbljenost zaradi slabega upravljanja prometa, po njihovem mnenju bi mnoge težave lahko rešili z doslednim izvajanjem prometnih predpisov. $\mathrm{Na}$ proučevanem območju so avtorji opazili samo najosnovnejše ukrepe za umirjanje prometa, kot so hitrostne ovire, drugih, kot so otoki za pešce, razširitve pločnikov ali srednji ločilni pasovi, pa ni bilo videti. Na sliki 4 je vidna samo ozka pregrada med prometnima pasovoma.

Zaradi opisanega stanja bi bilo treba na proučevanem območju uvesti dodatne ukrepe za umirjanje prometa, saj tam ni semaforjev za vozila ali pešce, kar povečuje nevarnost, da avtomobil zbije pešce. Po svetu je postala uvedba zvišanih prehodov za pešce in prometnih otokov splošna praksa, ki pešcem olajša premikanje po mestu in preprečuje trke. Kot je razvidno s slike 5, so na izbranem delu proučevanega območja vozniki ves dan parkirali avtomobile na ulici, kar je ustvarjalo nekakšen vmesni varovalni pas med pešci na pločniku in vozili na cesti. Zaradi tega so pešci lažje hodili po pločniku, težje pa so ob

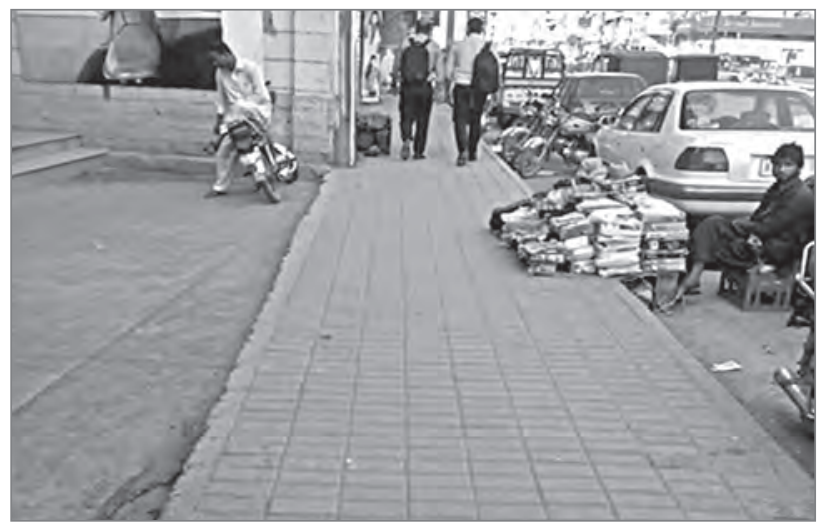

Slika 3: Ovire na pločnikih (foto: Maryam Aman)

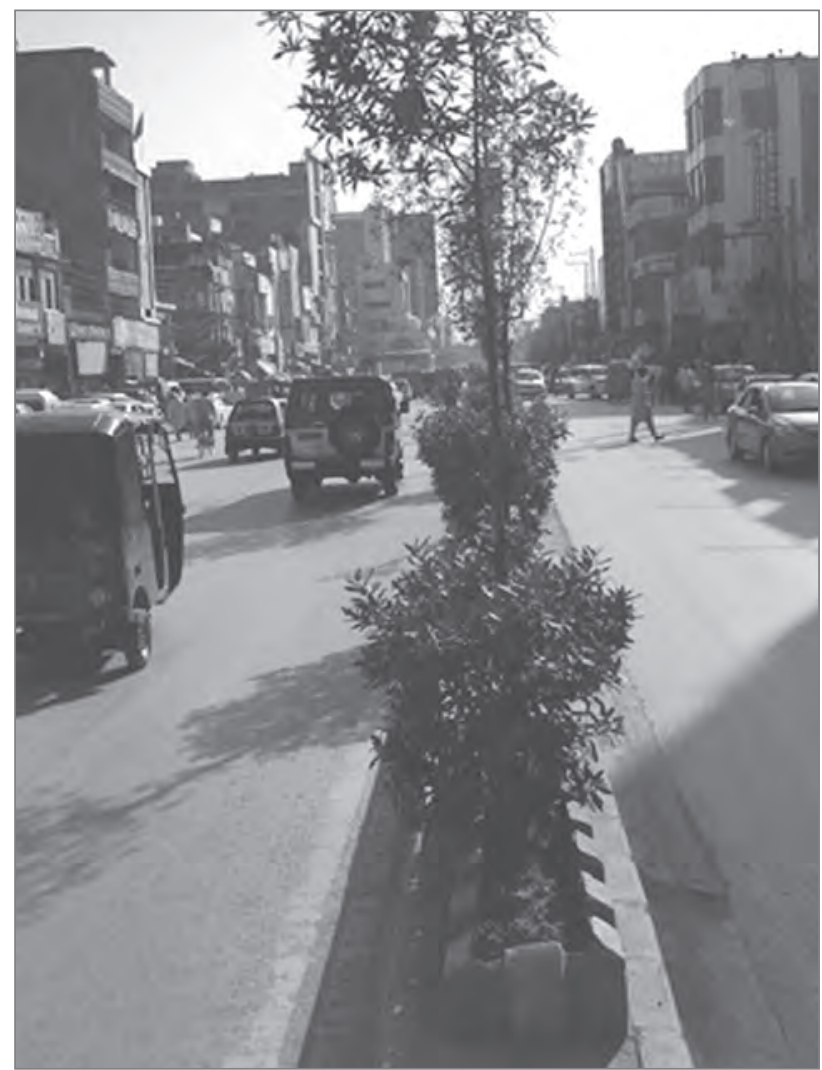

Slika 4: Primer upravljanja prometa v mestu (foto: Maryam Aman)

gostem prometu prečkali cesto. Na več mestih so bila na voljo urejena parkirišča zunaj ulic, ki so bila prav tako polno zasedena. Množično parkiranje na ulici in polno zasedena urejena parkirišča zunaj ulic kažejo na veliko uporabo avtomobilov na tem območju. Po svetu se odsvetuje uporaba osebnih vozil na trgovsko-poslovnih območjih in se spodbuja preurejanje ulic v območja za pešce, na proučevanem območju pa bo pomembno vlogo pri zmanjševanju uporabe avtomobilov imela uvedba javnega prometa.

Ukrepi za izboljšanje javnega prometa bi lahko imeli ključno vlogo pri zmanjšanju uporabe avtomobilov na proučevanem območju. Na njem ni parkirnih mest za invalide, kar vzbuja 
skrb, saj trenutna parkirišča ne zadovoljujejo potreb voznikov invalidov. Na ulici so ljudje ob pločnikih parkirali pravokotno ali postrani, kar je ustvarjalo varovalni pas za pešce, hkrati pa so s tem avtomobili zasedali precejšen del cestišča. To ogroža voznika parkiranega vozila in mimoidoča vozila, saj je vidljivost voznikov, ki parkirno mesto zapuščajo vzvratno, zelo slaba. $\mathrm{Na}$ mestih, kjer lahko vozniki avtomobilov parkirajo vzporedno z ulico, lahko pravokotno na ulico parkirajo tudi mopedisti in motociklisti. Uvedba pločnikov v mestnih središčih ima pomembno vlogo pri izboljšanju dinamike v mestu, saj izboljša življenjske razmere (Seskin in McCann, 2012). Na proučevanem območju so bili pločniki v precej slabem stanju, kar je pešcem povzročalo težave (to so navedli tudi anketiranci). Klančine na koncu pločnikov so bile precej strme, kar je zlasti ljudem na vozičkih oteževalo uporabo pločnika. Pločniki so bili široki približno $1,5 \mathrm{~m}$, ker pa so na njih tudi trgovine in ulični prodajalci razstavljali svoje blago in tako puščali le malo prostora za pešce, so ljudje zelo težko hodili po pločniku.

Na proučevanem območju ni bilo omembe vredne ulične opreme ali odprtih prostorov. Ob vsakem nakupovalnem centru so bili nameščeni ogromni reklamni panoji, ki so po mnenju anketirancev motili pozornost voznikov, zaradi česar bi lahko kateri izmed njih zbil pešca. Označbe parkirnih mest na ulici so zbledele in bi jih bilo treba prebarvati, da bi se parkirna mesta lahko razločila od cestǐ̌ča. Ulična oprema ima pomembno vlogo pri pritegovanju ljudi v poslovno središče mesta, saj ustvarja prijetno okolje za obiskovalce. To prispeva $\mathrm{k}$ boljšemu razvoju skupnosti in boljšim družbenoekonomskim razmeram v poslovnem središč in mestu na splošno. Proučevano območje je bilo na splošno precej onesnaženo, kar je razvidno tudi s slike 6. Anketiranci so zahtevali, da se na tem območju zagotovijo smetnjaki, saj bi pomagali zmanjšati onesnaževanje.

Skupni prometni prostor v glavnem temelji na konceptu zagotavljanja vseh prvin, ki jih potrebujejo uporabniki, ulična parkirišča pa so ena najpomembnejših prvin skupnega prometnega prostora na trgovsko-poslovnem območju (Bain idr., 2012). $\mathrm{Na}$ sliki 7 je prikazano zadovoljstvo anketirancev s parkirišči na proučevanem območju. Anketa je pokazala veliko nezadovoljstvo $s$ parkirišči na ulici, predvsem zaradi nezadostnega števila razpoložljivih parkirišč glede na močan pritok prometa. Zaradi slabega sistema javnega prevoza so se celo ljudje, ki živijo v bližini poslovnega središča, tja raje pripeljali z avtom. Drug razlog za nezadovoljstvo je bilo oteženo prečkanje ceste, ki kaže, da ukrepi za umirjanje prometa na tem območju niso uspešni. To zahteva uvedbo ukrepov, ki bi rešili težave, povezane z gostim prometom na proučevanem območju.

$S$ slike 7 je razvidno, da je bila polovica anketirancev poleg tega nezadovoljna s hojo in prečkanjem ceste ob gostem prometu. Na območju ni semaforjev, ki bi voznike opozarjali na

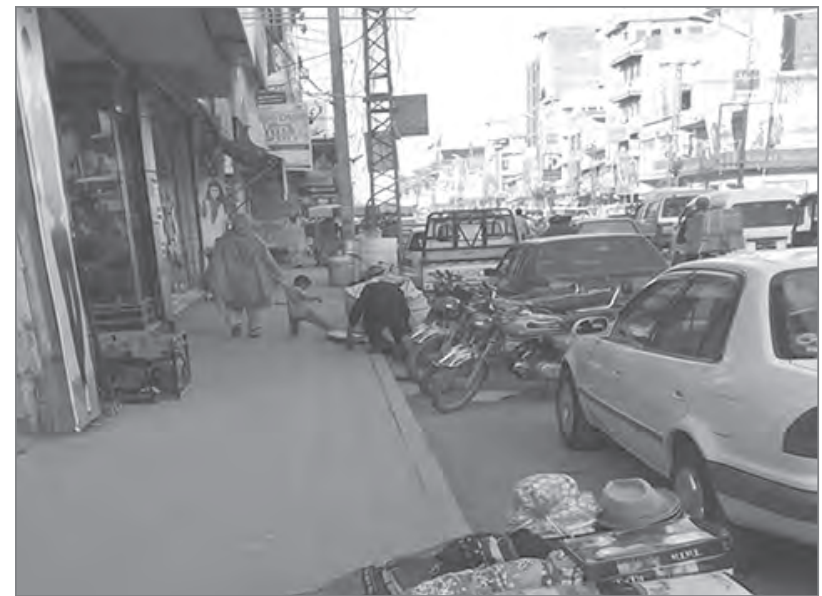

Slika 5: Parkiranje na trgovsko-poslovnem območju (foto: Maryam Aman)

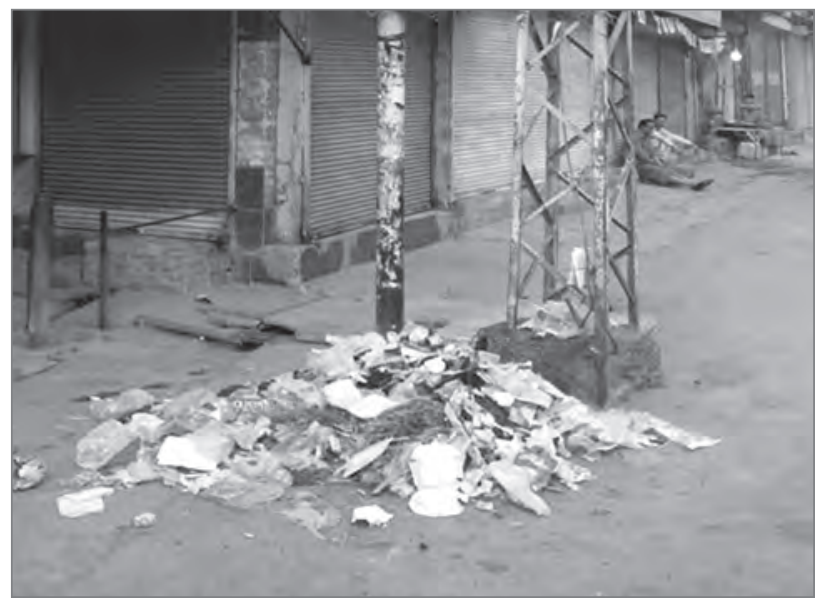

Slika 6: Pomanjkanje čistoče (foto: Maryam Aman)

to, kdaj se morajo ustaviti in pešcem omogočiti, da prečkajo cesto. Več kot polovica anketirancev je bila zadovoljna s hojo po pločnikih, saj so jim vozila, parkirana tik ob pločniku, kljub gostemu prometu dajala občutek varnosti. Ob trgovinah so potekali pločniki, kar je obiskovalcem olajšalo gibanje od ene trgovine do druge. Anketiranci so bili tudi dokaj zadovoljni s stanjem glede uličnega kriminala in sprehajanjem po pločnikih ponoči, saj sta več kot dve tretjini menili, da je območje varno. Ker na njem potekajo najrazličnejše gospodarske in druge dejavnosti, so nekatere izmed njih potekale tudi pozno v noč, zaradi česar je bilo območje tudi ponoči za obiskovalce varno. $S$ slike 7 je razvidno še, da je bila več kot polovica anketirancev nezadovoljna s trenutno infrastrukturo za pešce. Zadovoljni so bili s hojo po pločnikih, ne pa tudi z infrastrukturo za pešce na splošno. Glavna težava je bila, da ta infrastruktura ne poteka neprekinjeno in ni prilagojena obiskovalcem na invalidskih vozičkih. Tudi klančine na koncih pločnikov so zelo strme, kar starejšim in invalidom na vozičkih otežuje uporabo pločnikov. Na proučevanem območju bi se morali upoštevati največji dovoljeni koti klančin, kar bi ljudi vseh starosti in sposobnosti spodbujalo, da obiščejo poslovno središče. Na sliki 7 je prikazana stopnja zadovoljstva anketirancev s trenutno infrastrukturo 


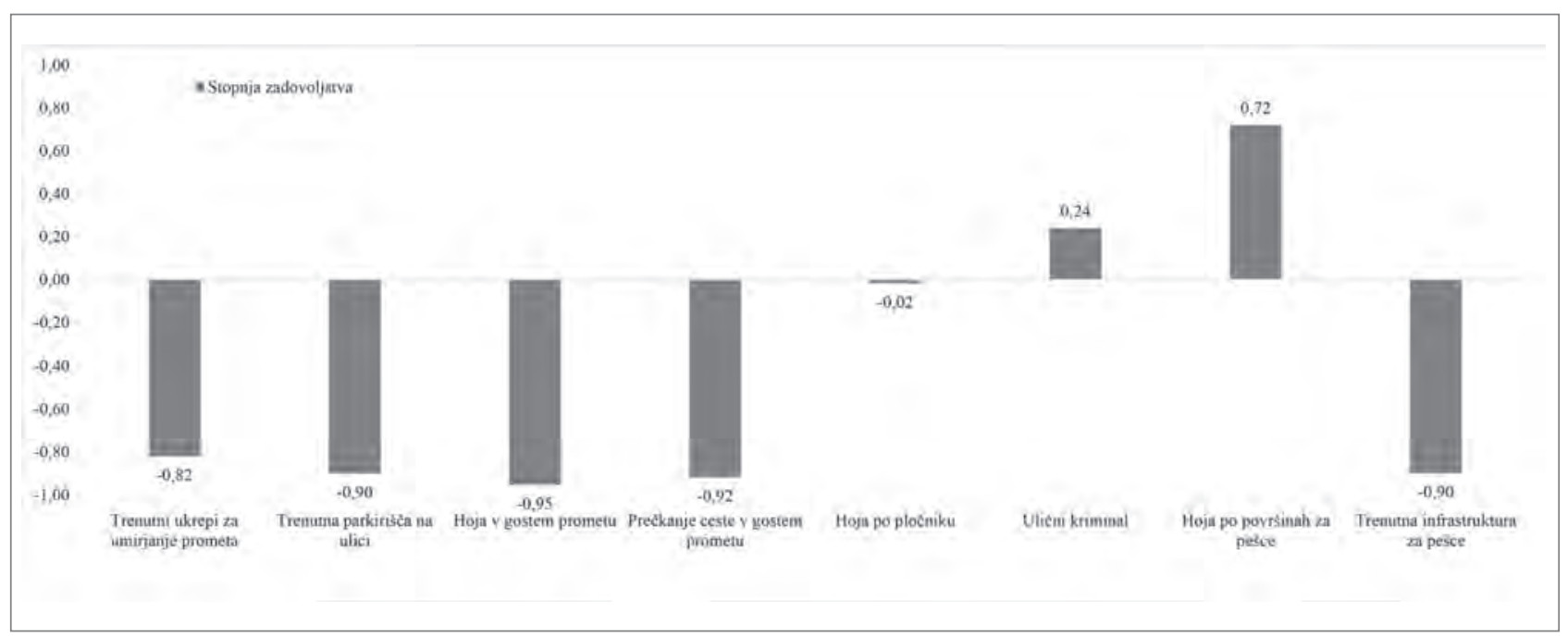

Slika 7: Zadovoljstvo anketirancev s trenutno infrastrukturo v poslovnem središču (vir: terenska raziskava)

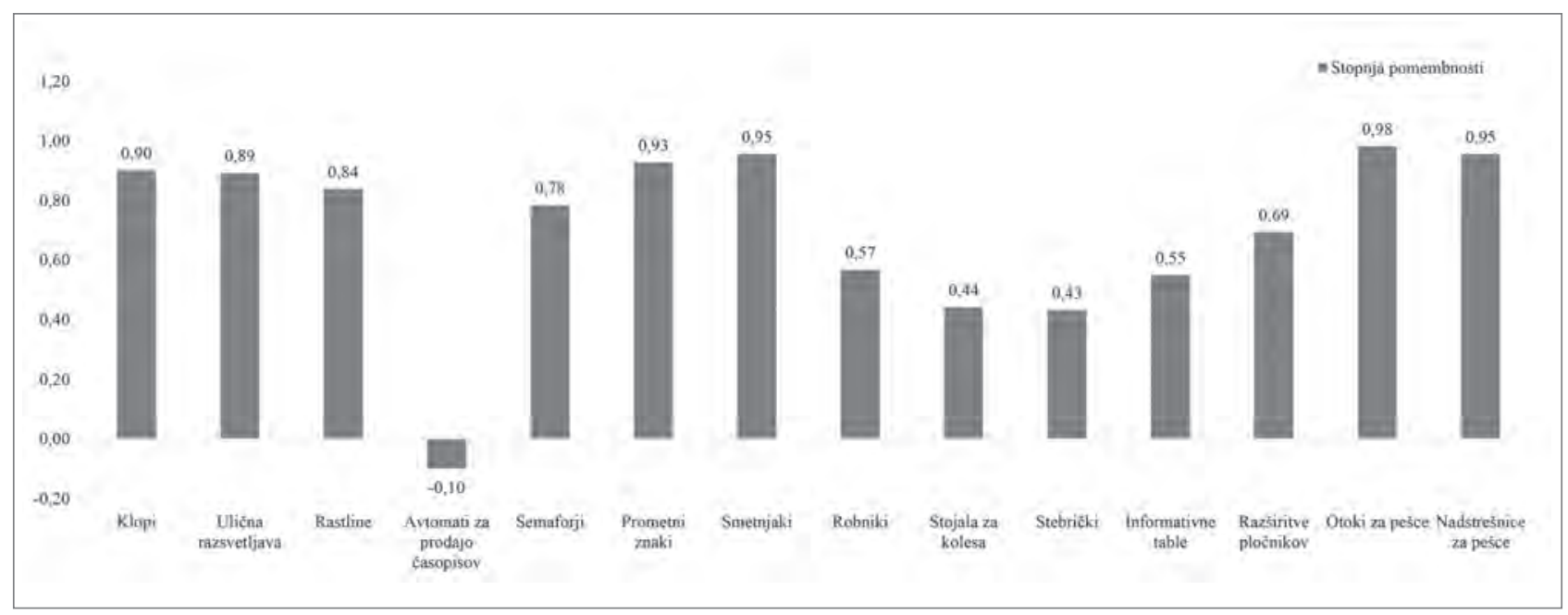

Slika 8: Najpomembnejše prvine skupnega prometnega prostora v poslovnem središču po mnenju anketirancev (vir: terenska raziskava)

v poslovnem središču Pešavarja. Negativne vrednosti izražajo nezadovoljstvo, pozitivne pa zadovoljstvo.

Cilj koncepta skupnega prometnega prostora je ljudi vrniti na ulice z izboljšanjem zunanjih površin za sedenje na podlagi oblikovanja javnih prostorov, privlačnih za pešce (Bain idr., 2012). Pločniki imajo pomembno vlogo pri lajšanju mobilnosti pešcev. Pri oblikovanju površin za pešce je treba paziti na to, da dopolnjujejo okoliško ulično krajino in ne sekajo ulic (Bain idr., 2012). Avtorji so od anketirancev pridobili podatke o trenutnih površinah za pešce na proučevanem območju. Raziskava je pokazala, da sta velika hitrost vozil in pomanjkanje prehodov za pešce med največjimi težavami, $s$ katerimi se spopadajo pešci na trgovsko-poslovnem območju, in sta najverjetneje posledica slabo urejenih pločnikov. Pešci se težko prebijajo skozi gnečo, saj so pločniki preozki, njihovo uporabo pa ovirajo tudi ulični prodajalci. Skupni prometni prostori prebivalcem sosesk omogočajo dostop do različnih družabnih dejavnosti, ki se spodbujajo z namestitvijo različne ulične opreme (Bain idr., 2012). V anketi so avtorji anketirance povprašali tudi o njihovem mnenju glede ulične opreme. Njihovi odgovori so prikazani na sliki 8 . Anketiranci so zahtevali namestitev klopi in ulične razsvetljave. Ker na proučevanem območju ni klopi, je več ljudi sedelo kar na robu pločnika. To nakazuje potrebo po klopeh in drugi ulični opremi.

Da bi v mestu ustvarili skupen prometni prostor, bi bilo treba izboljšati razsvetljavo in infrastrukturo za prečkanje cest, kar bi povečalo tudi varnost pešcev ponoči in podnevi (Zakaria in Ujang, 2015). Na proučevanem območju je bilo zelo malo uličnih svetilk, zato je bila vidljivost ponoči slaba. To pojasni željo anketirancev po boljši ulični razsvetljavi. Večina je zahtevala tudi namestitev semaforjev in prometnih znakov, saj jih na tem območju sploh ni. Večina je podpirala tudi namestitev smetnjakov, ki jih prav tako ni. Odsotnost smetnjakov na trgovsko-poslovnem območju lahko povzroči težave zaradi povečane količine smeti na ulici, kar ljudi odvrača od gibanja po ulicah in pločnikih. Več kot polovica anketirancev se 
je strinjala, da bi morali na proučevanem območju namestiti stojala za kolesa. To kaže, da so ljudje pripravljeni kolesariti, stojala pa bi jim olajšala parkiranje kolesa. Večina je podpirala tudi namestitev stebričkov in informacijskih tabel ter ureditev nadstrešnic za pešce, razširjenih pločnikov in otokov za pešce. Zagotavljanje naštetih prvin v poslovnem središču pomaga ustvariti vizualno in funkcionalno privlačno okolje, ki omogoča socialno enakost. $S$ slike 8 je razvidno, katere prvine ulične opreme so bile za anketirance najpomembnejše.

Poleg hoje je kolesarjenje eden najbolj zdravih načinov gibanja po mestu, saj pomaga reševati različna vprašanja, povezana z okoljem in skupnostjo, kot so kakovost življenja, podnebne spremembe, onesnaženost zraka in hrup. $V$ mestnih središčih pa so možnosti za kolesarjenje zaradi prometa pogosto omejene (Steinbach idr., 2011). Če bi se izboljšala potrebna infrastruktura, je kolesarjenju naklonjena večina anketirancev. Tretjina jih živi v predelih mesta, ki niso v neposredni bližini proučevanega območja, zato kolesarjenju niso bili naklonjeni, saj bi bila razdalja do poslovnega središča, ki bi jo morali prekolesariti, prevelika. Menili so, da bi bil dobro načrtovan javni prevoz zanje boljša rešitev.

Anketiranci so bili dokaj zadovoljni z varnostjo na pločnikih, zaradi velike hitrosti vozil pa so bili nezadovoljni z varnostjo pri prečkanju cest. Poleg tega so bili zaskrbljeni zaradi slabih ukrepov za umirjanje prometa. Ker na proučevanem območju ni razširitev pločnikov, pešci zelo težko prečkajo cesto v gostem prometu, ureditev razširjenih delov na pločnikih pa bi jim zagotovila večjo varnost pri prečkanju. Skoraj vsi anketiranci so se strinjali, da bi bilo treba sprejeti ustrezne ukrepe za usmerjanje pešcev $\mathrm{k}$ točkam, ki omogočajo varno prečkanje ceste, saj so zaradi čedalje večjega števila prometnih nesreč tovrstni ukrepi ključni za varnost uporabnikov proučevanega območja.

\section{Sklep}

V članku so avtorji analizirali trgovsko-poslovne ulice v Pešavarju, da bi opredelili trenutne težave in možnosti oblikovanja trajnostnih ulic, privlačnih za bivanje. Pešavar je mesto v Pakistanu, v katerem primanjkuje mnogo infrastrukture, ki bi zadovoljila potrebe vseh udeležencev v prometu, zlasti v njegovem poslovnem središču. Posledično njegov razvoj ni trajnosten, kar vpliva na kakovost življenja prebivalcev in obiskovalcev, zlasti zaradi težav, kot so onesnažen zrak, hrup, slabo upravljanje prometa, pomanjkanje ulične opreme, slaba infrastruktura za pešce in pomanjkanje kolesarske infrastrukture. Ta vprašanja niso vključena v mestne načrtovalske dokumente, saj se ti osredotočajo predvsem na motorizirani promet. Vzrok za to bi bilo lahko to, da oblast slabo razume pomen preurejanja ulic v območja za pešce. Glavni cilj uvedbe skup- nega prometnega prostora v mestu je narediti mesto živahno in dostopno za prebivalce. $Z$ njo postanejo alternativni načini prevoza ljudem privlačnejši, hkrati pa spodbudi preobrazbo javnih prostorov, s čimer postanejo ulice varnejše in živahnejše. $\mathrm{V}$ raziskavi, navedeni v tem članku, so avtorji proučevali glavno trgovsko-poslovno vozlišče v Pešavarju, njeni izsledki pa bi bili lahko podlaga za sprejetje ustreznih ukrepov za izboljšanje okoljskih in družbenoekonomskih razmer v mestu. Raziskava je razkrila težave, kot so hrup, onesnažen zrak, smeti, pomanjkanje ustrezne javne prometne infrastrukture, slabo upravljanje prometa in pomanjkanje infrastrukture za pešce (zlasti invalide in starejše). Izsledki potrjujejo hipotezo, da neustrezna infrastruktura v poslovnem središču Pešavarja negativno vpliva na splošne družbenoekonomske razmere.

Uvedba koncepta skupnega prometnega prostora na proučevanem območju bi spodbudila oblikovanje zdravih skupnosti, izboljšala kakovost življenja in razmere v soseskah ter domačine spodbudila $\mathrm{k}$ preobrazbi javnih prostorov. Z vključitvijo skupnega prometnega prostora v mestno krajino Pešavarja bi torej pomagali oblikovati trajnostno okolje $\mathrm{v}$ mestu.

\section{Maryam Aman}

National Institute of Transportation, School of Civil and Environmental Engineering, National University of Sciences and Technology (NUST), Islamabad, Pakistan

E-naslov: maryamaman09@gmail.com

Abdul Waheed

National Institute of Transportation, School of Civil and Environmental Engineering, National University of Sciences and Technology (NUST), Islamabad, Pakistan

E-naslov:drwaheed@nit.nust.edu.pk

\section{Malik Asghar Naeem}

National Institute of Transportation, School of Civil and Environmental Engineering, National University of Sciences and Technology (NUST), Islamabad, Pakistan

E-naslov: asghar.naeem@nit.nust.edu.pk

Syed Akhtar Ali Shah

Urban and Regional Planning Department, University of Peshawar, Pešavar, Pakistan

E-naslov: shahg@uop.edu.pk

\section{Viri in literatura}

Abdu, A., Hashim, A. H., Samah, A. A., in Salim, A. S. S. (2014): Relationship between background characteristics and residential satisfaction of young households in unplanned neighbourhoods in Kano, Nigeria. IOSR Journal of Humanities and Social Science, 19, str. 138-145. DOI: 10.9790/0837-19108138145

Ali, Z., Shah, S. A. A., in Hussain, A. (2012): Growing traffic in Peshawar: An analysis of causes and impacts. South Asian Studies, 27(2), str. 409-420.

Anwar, H. N., Perveen, S., Mehmood, S., in Akhtar, S. (2008): Assessment of farmer's attitude towards participatory irrigation management in Punjab-Pakistan. Pakistan Journal of Life and Social Sciences, 6(2), str. 121-126. 
Appleyard, B., Ferrell, C., Carroll, M., in Taecker, M. (2014): Toward livability ethics: A framework to guide planning, design, and engineering decisions. Transportation Research Record: Journal of the Transportation Research Board, 2403, str. 62-71. DOI: 10.3141/2403-08

Bain, L., Gray, B., in Rodgers, D. (2012): Living streets: Strategies for crafting public space. Hoboken, NJ, John Wiley \& Sons.

Barnett, J. (2018): The fractured metropolis: Improving the new city, restoring the old city, reshaping the region. Abingdon, VB, Routledge. DOI: 10.4324/9780429492822

Bhattacharyya, D. B., in Mitra, S. (2013): Making Siliguri a walkable city. Procedia - Social and Behavioral Sciences, 96, str. 2737-2744. DOI: 10.1016/j.sbspro.2013.08.307

Borthakur, A. (2017): Afghan refugees: The impact on Pakistan. Asian Affairs, 48(3), str. 488-509. DOI: 10.1080/03068374.2017.1362871

Burden, D., in Litman, T. (2011): America needs complete streets. ITE Journal, 81(4), str. 36-43.

Carmona, M. (2010): Public places, urban spaces: The dimensions of urban design. Abingdon, VB, Routledge.

Chourabi, H., Nam, T., Walker, S., Gil-Garcia, J. R., Mellouli, S., Nahon, K., idr. (2012): Understanding smart cities: An integrative framework. Prispevek je bil predstavljen na konferenci z naslovom 2012 45th Hawaii International Conference on System Sciences, ki je potekala od 4. do 7. januarja v Mauiju na Havajih. Tipkopis. DOI: 10.1109 /hicss.2012.615

Datey, A., Darji, V., Patel, T., in Mahadevia, D. (2012): Walking and cycling in Indian cities: A struggle for reclaiming road edges. Ahmedabad, Center for Urban Equality (CUE). Dostopno na: https://cept.ac.in/UserFiles/File/ CUE/Working\%20Papers/Revised\%20New/18CUEWP18_Walking\%20 and\%20Cycling\%20in\%20Indian\%20Cities $\% 20 \mathrm{~A} \% 20$ Struggle $\% 20$ for $\% 20$ Reclaiming\%20Road\%20Edges.pdf (sneto: 13. 2. 2019).

Dempsey, N., Bramley, G., Power, S., in Brown, C. (2011): The social dimension of sustainable development: Defining urban social sustainability. Sustainable Development, 19(5), str. 289-300. DOI: 10.1002/sd.417

Dumbaugh, E., in Gattis, J. (2005): Safe streets, livable streets. Journal of the American Planning Association, 71(3), str. 283-300. DOI: 10.1080/01944360508976699

Eckerson, C. (2010): Portland's bike boulevards become neighbourhood greenways. Street Films. Dostopno na: https://www.streetfilms.org (sneto 13. 6. 2019).

Farr, D. (2011): Sustainable urbanism: Urban design with nature. Hoboken, NJ, John Wiley \& Sons.

Gehl, J. (2011): Life between buildings: Using public space. Washington DC, Island Press.

Gehl, J. (2013): Cities for people. Washington DC, Island Press.

Google (2019) Zemljevid proučevanega območja. Dostopno na: https:// www.google.com/maps/search/peshawar+saddar/@33.9973018,71.5393 $431,17 z$ (sneto 13. 6. 2019).

Gulzar, S., Yahya, F., Mir, Z., in Zafar, R. (2012): Provincial analysis of traffic accidents in Pakistan. Academic Research International, 3(3), str. 365-374.

Hashmi, S. M. (2016): An empirical analysis of low-income housing, policies and public finance of Pakistan. Doktorska disertacija. Jokohama, Yokohama National University.

Hou, J. (2010): Insurgent public space: Guerrilla urbanism and the remaking of contemporary cities. Abingdon, VB, Routledge. DOI: 10.4324/9780203093009

Hyder, A. A., Ghaffar, A., in Masood, T. I. (2000): Motor vehicle crashes in Pakistan: The emerging epidemic. Injury Prevention, 6(3), str. 199-202. DOI: 10.1136/ip.6.3.199
Krejcie, R. V., in Morgan, D. W. (1970): Determining sample size for research activities. Educational and Psychological Measurement, 30(3), str. 607-610. DOI: 10.1177/001316447003000308

Leather, J., Fabian, H., Gota, S., in Mejia, A. (2011): Walkability and pedestrian facilities in Asian cities. State and issues (=ADB Sustainable Development Working Paper Series 17). Manila, Asian Development Bank.

Lennard, S. C. L. (2008): The principle of true urbanism. Dostopno na: http://www.livablecities.org/articles/principles-true-urbanism (sneto 30. 4. 2017).

Majeed, H. A. (2012): Urban regeneration: The case of Penang, Malaysia. Putting policy into practice. Kuala Lumpur, Khazanah Nasional.

McPherson, E. G., Simpson, J. R., Peper, P. J., in Xiao, Q. (1999): Tree guidelines for San Joaquin Valley communities. Sacramento, CA, Local Government Commission.

Miller, H. J., Witlox, F., in Tribby, C. P. (2013): Developing context-sensitive livability indicators for transportation planning: A measurement framework. Journal of Transport Geography, 26, str. 51-64. DOI: 10.1016/j.jtrangeo.2012.08.007

Nilles, M. (2016): Analysing the walkability of a pedestrian network. Journal of Transport \& Health, 3(2), str. S16. DOI: 10.1016/j.jth.2016.05.050

Pojani, D., in Stead, D. (2015): Sustainable urban transport in the developing world: Beyond megacities. Sustainability, 7(6), str. 7784-7805. DOI: $10.3390 /$ su7067784

Pucher, J., in Buehler, R. (2011): Analysis of bicycling trends and policies in large North American cities: Lessons for New York. New York, University Transportation Research Center.

Seskin, S., in McCann, B. (2012): Complete streets policy analysis 2011. Washington, DC, Smart Growth America.

Shaftoe, H. (2012): Convivial urban spaces: Creating effective public places. London, Earthscan. DOI: 10.4324/9781849770873

Shah, S. A. A. (2014): Road accident statistics of district Peshawar 2003 - 2012. Pešavar, Urban Policy Unit.

Shamsuddin, S., Hassan, N. R. A., in Bilyamin, S. F. I. (2012): Walkable environment in increasing the liveability of a city. Procedia - Social and Behavioral Sciences, 50, str. 167-178. DOI: 10.1016/j.sbspro.2012.08.025

Soltani, A., in Bosman, C. (2005): Evaluating sustainable urban form: Comparing two neighbourhood development patterns in Adelaide. Prispevek je bil predstavljen na konferenci z naslovom 2nd State of Australian Cities Conference: The Sustainability and Vulnerability of Urban Australia, ki je potekala od 30. novembra do 2. decembra v Brisbanu v Avstraliji. Tipkopis.

Sreetheran, M., Adnan, M., in Azuar, A. K. (2011): Street tree inventory and tree risk assessment of selected major roads in Kuala Lumpur, Malaysia. Arboriculture and Urban Forestry, 37(5), str. 226-235.

Steinbach, R., Green, J., Datta, J., in Edwards, P. (2011): Cycling and the city: A case study of how gendered, ethnic and class identities can shape healthy transport choices. Social Science \& Medicine, 72(7), str. 1123-1130. DOI: 10.1016/j.socscimed.2011.01.033

Yeh, S. H. (1972): Homes for the people: A study of tenants' views on public housing in Singapore. Washington, DC, US Government Printing Office.

Yeh, S. H. K. (1975): Public housing in Singapore: A multidisciplinary study. Singapur, Singapore University Press.

Zakaria, J., in Ujang, N. (2015): Comfort of walking in the city center of Kuala Lumpur. Procedia - Social and Behavioral Sciences, 170, str. 642652. DOI: 10.1016/j.sbspro.2015.01.066 